\title{
Website Babies Portal: development and evaluation of the contents regarding orofacial functions
}

\author{
Camila de Castro CORRÊA ${ }^{1}$, Adriana Regina Colombo PAULETO ${ }^{2}$, Deborah Viviane FERRARI ${ }^{1}$, Giédre BERRETIN- \\ FELIX'
}

1- Department of Speech-Language Pathology and Audiology, Bauru School of Dentistry, University of São Paulo, Bauru, SP, Brazil.
2- Department of Pediatric Dentistry, Bauru School of Dentistry, University of São Paulo, Bauru, SP, Brazil.

Corresponding address: Camila de Castro Corrêa - Al. Octávio Pinheiro Brisolla, 9-75 - 17012-901 - Bauru - São Paulo - Brazil - Phone: +55 14981175708 - e-mail: camilacorrea@usp.br

Submitted: March 26, 2013 - Accepted: September 12, 2013

\section{ABSTRACT}

\begin{abstract}
Education mediated by technology facilitates the access to information and can reach more people, including a broader range of socio-economic groups and ages, and at a low-cost. The website "Babies Portal - Speech-Language Pathology/Audiology and Dentistry" (http://portaldosbebes.fob.usp.br) was developed to provide parents with information on communication procedure disorders and oral health, enabling them to prevent and identify any changes in development early while looking for the best treatment. Objective: The objective is to describe the development and evaluation of the content pertaining to the oral functions featured in the "Babies Portal". Methods: The first stage consisted of a literature review, development/selection of illustrations and an evaluation of the possible external links that could be available. In the second stage, 10 speech-language and hearing pathologists (group A) and five parents of babies (group B) evaluated the website via an online form, which included ethical and personal information and questions about the quality, technical information and comparative prior knowledge acquired after the access. In the first stage, there was the construction of five sections ("The Oral Functions", "Breastfeeding", "Food", "Pacifier, baby bottle and finger sucking" and "Breath") based on scientific studies, presenting objective information, content links prepared by the Ministry of Health and a Dentistry section in the "Babies Portal" website. Videos, static and dynamic images were also distributed throughout the sections. Results: Regarding the second stage, $90 \%$ of all speech-language and hearing pathologists judged a good/excellent quality for all sections and classified the technical quality as very good. By their turn, $88 \%$ of the parents (group B) reported that the website helped or helped very much in understanding the contents, and $80 \%$ rated the quality as good or excellent. Conclusions: Five sections concerning the oral functions were structured, and the results collected from groups A and B suggest that the content provided is adequate and reliable.
\end{abstract}

Key words: Speech, language and hearing sciences. Breast feeding. Pacifiers. Distance education. Primary prevention.

\section{INTRODUCTION}

Exclusive Breastfeeding should be conducted up to six months into the baby's life, and, from this age, complementary foods should be introduced. This recommendation is due to the fact that breastfeeding provides many benefits to the baby, such as adequate nutrition, protection against mortality from diarrhea ${ }^{10}$, development of orofacial structures and functions ${ }^{13}$, psychological development ${ }^{21}$, and the mother also benefits, as to the economy ${ }^{1}$ and disease prevention for both ${ }^{14}$.

Another benefit of breastfeeding is the prevention of harmful oral habits such as finger sucking, baby bottle, pacifier and oral breathing ${ }^{17}$. These habits lead to greater chances of occlusal changes ${ }^{28}$, speech, chewing and swallowing ${ }^{26}$. If the duration of the breastfeeding is longer, the chances of the baby acquiring the habit of non-nutritive sucking are lower ${ }^{15}$. 
The development of harmful oral habits and the early diet changes of the child are directly related to the time and form of exclusive breastfeeding and complementary feeding ${ }^{27}$. In addition to oral habits and food, sociocultural, economic, lack of prenatal care and the mother's age are related to early weaning 22 .

In early childhood, a baby may present changes in the orofacial functions. It is important to alert the parents and caregivers about these possible changes in order to prevent them or facilitate an early diagnosis and intervention, which can minimize or eliminate them ${ }^{4}$.

The development of Internet-based communication strategies for the healthcare field can enable the delivery of relevant information and motivate the guidance that complements or strengthens the education otherwise taught through more traditional channels.

The literature suggests a greater dissemination of information about correct complementary feeding ${ }^{16}$ with an appropriate language for the diversification of the audience, parents and caregivers of different realities, characterized by objectivity and clarity, ensuring success in the transmission of the message ${ }^{20}$.

Studies show that parents may be able to identify changes in children but lack the knowledge of the consequences, such as those coming from not looking for an appropriate early treatment ${ }^{3}$.

Education mediated by technology is viewed as a means for self-learning that can reach more people, including a broader range of socio-economic groups and ages, through low-cost access ${ }^{12}$, such as researchers in the Telehealth group at the Bauru School of Dentistry, University of São Paulo. The website was created in order to provide parents and caregivers information about the processes, communication disorders and the oral health of young children. For this, it uses a simple and friendly language, as well as the use of interactive animations, videos and photos.

This study's aim was to develop the website Babies Portal's sections concerning the orofacial functions, covering the content of breastfeeding, nutrition, breathing and oral habits, and to evaluate the quality of the website concerning technical information and how this contributed to learning.

\section{MATERIAL AND METHODS}

The study was conducted in two stages, having been approved by the Ethics Committee of the Bauru School of Dentistry, University of São Paulo (process 001/2010).
First stage - Development of the sections concerning orofacial functions

In order for the content to be scientifically supported, a survey was conducted using the databases LILACS and Medline from the intersection of the keywords: "Breastfeeding, Habits, Pacifiers, Feeding, Complementary feeding, Bottle feeding, Breathing, Breathing and Swallowing". Internet search engines like Google ${ }^{\mathrm{TM}}$ were also used. The study included articles that met the following inclusion criteria: addressing the aspects of normal and/or alterations of the stomatognathic system and oral functions, behavior and provide guidance to parents, caregivers and/or professionals in cases of orofacial, myofunctional disorders, quote form preventions of changes in sucking, breathing, chewing, swallowing and speech, having been published in the period from 1998 to 2008.

\section{Second stage - Evaluation of the readability level}

We then transformed the scientific technical discourse into common speech, making the website's language understandable for a broad lay audience, including various age groups, educational levels, and socioeconomic factors. The readability of the text was evaluated by the Flesch Reading Ease Test. For this, the text was inserted in the tool, Microsoft Office Word and check spelling and grammar in the end of the program, which provided a score on the readability of the text on a scale of 100 points; the higher the score, the easier it is to understand the document. It is classified as Very Easy (90 to 100 points), Easy (80 to 90 points), Reasonably Easy (70 to 80 points, mean of 60 to 70 points), Reasonably Difficult (50 to 60 points), Difficult (40 to 50 points) and Very Difficult (0 to 30 points). For the standard files, the score should be between 60 and 70 points ${ }^{5}$.

\section{Third stage - Evaluation of the website (pilot study)}

Participants: parents and speech-language pathologists/audiologists who work at or frequent the Clinic for Hearing and Speech Pathology of Bauru School of Dentistry - University of São Paulo or who accepted an invitation sent by e-mail for access to the "Orofacial Functions" section of the Babies Portal website and marked the Clear Informed and Terms Consent, composed of two groups of volunteers:

Group A: 10 speech-language pathologists/ audiologists (female) aged 22 to 37 years (mean 26.8 years). Eight participants were single and two were married, inhabitants of the cities of Bauru/SP (6 participants) Marília (1 participant), Piratininga (1 participant), Jundiaí (1 participant) and Piracicaba (1 participant). Regarding the academic 
formation, $60 \%$ were graduates, $20 \%$ experts and $20 \%$ Masters. Regarding the information to access the Internet, $100 \%$ access the Internet several times a day, 70\% access the Internet at home and $30 \%$ at work, using broadband ( $90 \%)$ and cellular $(10 \%)$. As for the time of graduation of SpeechLanguage Pathology/Audiology were found: 1 year = 2 speech-language pathologists/audiologists; 1 to 5 years $=6$ participants; 5 to 10 years $=1$ speechlanguage pathologists/audiologists); and 10 to 15 years $=1$ participant.

Group B: five adults (one female and 4 male), aged 22 to 33 years (mean 26.6 years) parents of children under the age of 36 months. The participants were all from the state of São Paulo, 3 from Bauru, 1 from Guarulhos and 1 from Vargem Grande do Sul. The Internet access information showed that 4 participants access the Internet several times a day and one participant often (several times a week), $80 \%$ use the Internet from home and $20 \%$ from work. In both cases, the access was done by a broadband connection type. As for the users' personal information, it was found that the marital status was single for three and two were married. In relation to schooling, 4 did not complete high school and 1 completed high school. The monthly income of 2 families was 3 to 5 minimum wages $(1,530.00$ to $2,550.00 \mathrm{BRL})$, for the other 2 families, it was 5 to 8 minimum wages $(2,550.00$ to $4,080.00 \mathrm{BRL})$ and, for another family, 8 to 12 minimum wages $(4,080.00$ to $6,120.00$ $B R L)$. Four of the participants reported having a child of the ages: up to 3 months, 3 to 6 months, 18 to 24 months and more than 36 months; and another participant reported having two children of 12 to 18 months of age.
Procedures: The participants were asked to access the following Babies Portal sections: "The Oral Functions", "Breastfeeding", "Food", "Pacifier, baby bottle and finger sucking" and "Breath", as well as to answer the forms available online during one month. The information about the forms used is described below:

Form for group A: it was composed of three parts: the first consisted of 9 questions about personal information (including general information, academic formation and about Internet use). Part two consisted of 6 multiple choice questions to assess the general quality of the contents of the oral functions in the website (which ranged from poor to excellent), while the third contained 7 multiple-choice questions based on the principles of ownership, purpose, authoring, interactivity and health updates on the Net Code (HON Code) modified (2) to assess the quality of technical information. Each of these characteristics has been subdivided into items that received a score of 0,1 or 2 (depending on the information quality provided). The higher the score (for a total of 13 points) the better the website quality.

Form for group B: it was also composed of two parts: the first contained 12 questions about personal information (general data, family income, children and data on Internet use). The second part had 9 multiple-choice questions to assess how much the content helped in learning compared to their prior knowledge, determined by the subject of every topic. They were given the following options: "not helped", "helped little", "helped", "helped very much" and "did not access this part".

At the end of the forms, the two groups were able to make comments, criticisms or suggestions

\begin{tabular}{|l|l|}
\hline SECTION & CONTENTS \\
\hline "The orofacial functions" & $\begin{array}{l}\text { Introduction about the contents to be addressed in other developments of } \\
\text { the baby Orofacial Myology topics. }\end{array}$ \\
\hline "Breastfeeding" & $\begin{array}{l}\text { Advantages that the baby and mother have with this activity. Preparation } \\
\text { of the mother during pregnancy for the act of breast-feeding. The ten steps } \\
\text { of how to breast-feed the baby. The most difficulties in breast-feeding for } \\
\text { the mother and her child. Providing solutions for them and even when it is } \\
\text { recommended that the mother breast-feed. }\end{array}$ \\
\hline "Food" & $\begin{array}{l}\text { Nutrition of } 6 \text { until } 24 \text { months of the baby's life. Addressing the consistency } \\
\text { to be given in certain groups' ages. The amount of food being offered and } \\
\text { how often the baby must be fed. Which ideal foods and how these should } \\
\text { be cleaned. }\end{array}$ \\
\hline "Pacifier, baby bottle and finger sucking" & $\begin{array}{l}\text { The consequences of harmful oral habits, when they should be removed and } \\
\text { ways to prevent them. }\end{array}$ \\
\hline "Breath" & $\begin{array}{l}\text { The importance of nasal breathing and their benefits. The steps to correct } \\
\text { nasal hygiene and increased incidence of respiratory problems in infants } \\
\text { and indicating the causes and treatments. }\end{array}$ \\
\hline
\end{tabular}

Figure 1- Description of the content placed in the five sections built on the wing orofacial functions 
through an open question format.

\section{Data analyses}

The analyses of the results were descriptive from the averages of the Flesch Reading Ease indices, the responses collected from the questionnaires from the parents and speech therapists. The average score for each section of the orofacial functions were considered, as well as the overall average of each of these aspects.

\section{RESULTS}

First stage - Development of the sections concerning the orofacial functions

The search resulted in the recovery of 30 scientific articles whose contents were then organized. Also, 16 websites were found about the topics, and an abstract with a critical analysis for each material was carried out. The study showed that few works are available in print and online, and that, although scarce, these contents are reliable and complete from the scientific point of view.

The contents collected were then organized in the form of texts and topics, bringing exact and objective information to interested readers and to access a wider range of content based on science.

The information was divided into five sections: "The Oral Functions", "Breastfeeding", "Food", "Pacifier, baby bottle and finger sucking" and "Breath", as shown in Figure 1.

To facilitate the comprehension of specific contents of Speech-Language Pathology/Audiology and the Health area, definitions of the Glossary of the website were used. In this section, a dictionary was organized for all the definitions that were needed.

Among the websites found, there were Child Health, Ministry of Health Portal (http://portal.saude. gov.br/portal/saude/area.cfm?id_area $=1251$ ), which enabled the selection of information for availability in the links of Babies Portal, using the existing quality and reliability material, which connected the Babies Portal website with the materials from the Ministry of Health. We followed the guidelines recommended by the Ministry of Health, providing the information regarding how long the mother should breastfeed her child, for example.

Internal links were also inserted that provide fast access to specific contents of Dentistry of the Babies Portal website. In addition, links to the audiology section of the Portal were also included. In order to complement the content and provide access to more content of the website, links were also provided between the sections "The Oral Functions", "Breastfeeding", "Food", "Pacifier, baby bottle and finger sucking" and "Breath".

Static pictures were devised as much to make the content more interesting as to facilitate the understanding of the information functioning as diagrams. Both functions of the images serve to increase the understanding and fixing of the content of the website user. In conclusion, dynamic images were inserted in the "Breastfeeding" and "Food" sections, for a total of eight videos, as shown in the selections from the Experimental IPTV Bauru School of Dentistry, University of São Paulo (designed to

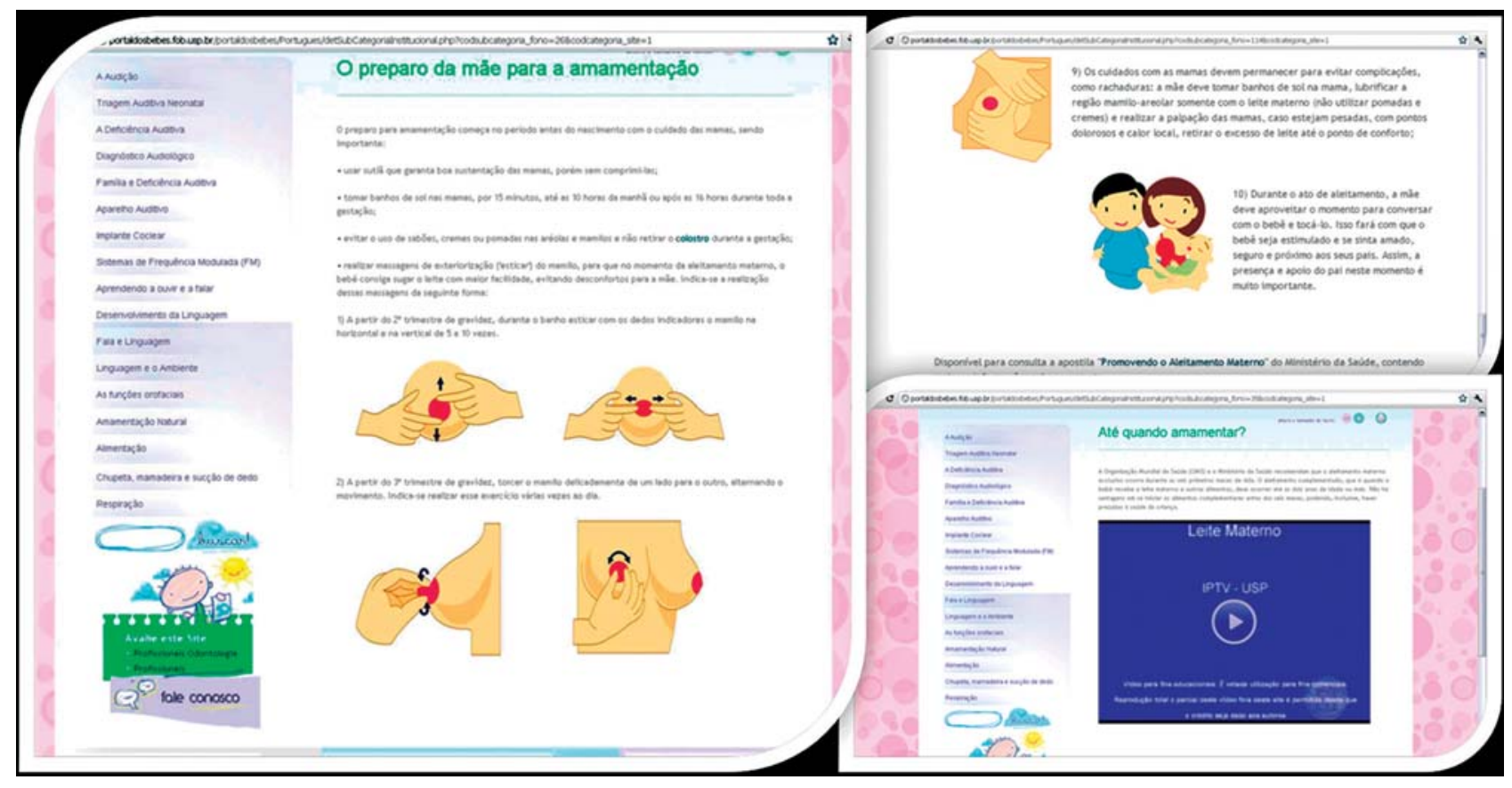

Figure 2- Examples of the static images and videos of the Experimental IPTV - Bauru School of Dentistry, University of São Paulo, available in the Orofacial Section of the Babies Portal website 
improve the management mechanisms for the distribution of video services on the Internet) channel of the series Breastfeeding (http://iptv. usp.br/portal/videos.jsp?_contexto=grupo\&_ idContexto $=81$ ). Figure 2 , below, exemplifies the availability of the static images and videos.

\section{Second stage - Evaluation of the readability level}

The language was adapted to make it available for the diversity of the audience, and the evaluation of the language of the Babies Portal website was carried out by the Flesch Reading Ease Test. Figure 3 shows the test results for each of the five sections. Considering that the average obtained for the different sections was 60.8 with a standard deviation of 4.44 , we obtained a level considered a standard readability of the content related to the topics "The Oral Functions", "Breastfeeding", "Food", "Pacifier, Baby Bottle and Finger Sucking" and "Breath" by the score between 50 and 70 points.

From this, we carried out a study on the concepts covered in each section, having selected the static and dynamic images that facilitate learning. External links were also evaluated which would be available to complement the information.

\section{Third stage - Evaluation of the website (pilot study) \\ Regarding the assessment and the quality of} the Babies Portal website by speech-language pathologists/audiologists, the results are presented in Figure 4. We obtained the optimal classification for $50 \%$ or more of the participants in the five developed sections. There was not a poor quality rating in any section. The majority of the interviewees judged a good and excellent quality for the all sections, indicating a high level of satisfaction for the construction of the sections on the website in the Orofacial Myology area.

Question 16 from the form was answered by the speech-language pathologists/audiologists with suggestions that they would elaborate and comment on, if deemed necessary. Such information

\section{Readability level of website} language

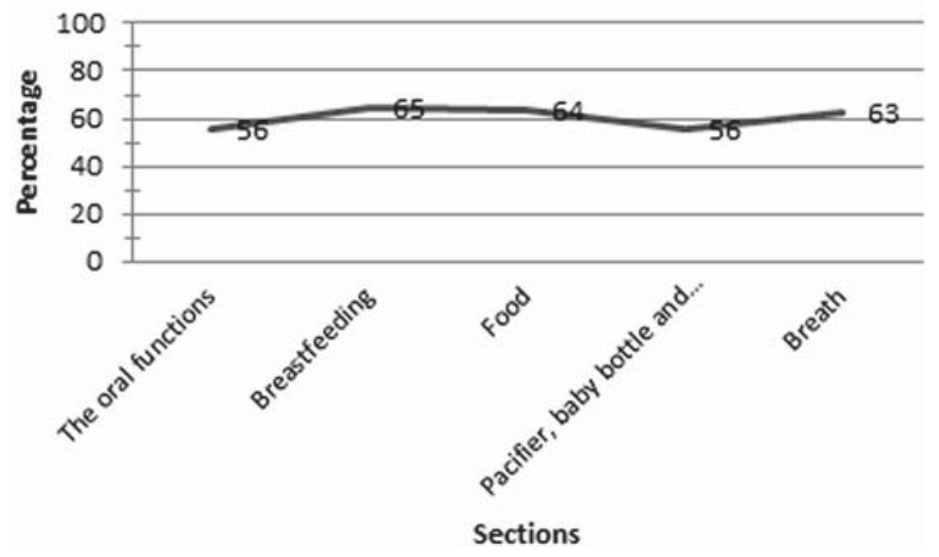

Figure 3- Scoring of the level of readability of the language of the website, obtained by applying the Flesch Reading Ease Test, for each of the sections

\begin{tabular}{|c|c|c|c|c|c|}
\hline & & & & & \\
\hline $\begin{array}{c}\text { Acquisition of } \\
\text { new information }\end{array}$ & $\begin{array}{c}\text { The Oral } \\
\text { Functions }\end{array}$ & Breastfeeding & Food & $\begin{array}{c}\text { Pacifier, Baby } \\
\text { bottle and Finger } \\
\text { sucking }\end{array}$ & Breath \\
\hline No help & - & - & - & - & - \\
\hline Helped a little & 20 & 40 & - & 60 & - \\
\hline Helped & 40 & 20 & 60 & 40 & 60 \\
\hline Helped a lot & 40 & 40 & 40 & 40 \\
\hline
\end{tabular}

Figure 4- Presentation of the professionals' percentage, according to the classification of the quality of each section of the website 
is arranged in Figure 5. From the comments made, it was observed that two participants positively assessed the work done, since the other comments were made up of questions or suggested enhancements to the site and the information provided to parents and caregivers of infants up to 3 years of age.

Upon the suggestion of the inclusion of the specific instructions on the elimination of harmful habits (comment 4 of Figure 5), the construction of a new section was carried out with 10 steps for the removal of finger sucking and pacifier habits (http://portaldosbebes.fob.usp.br/portaldosbebes/ Portugues/detInstitucional.php?codcategoria_ site $=1 \&$ codinstitucional_fono=76).
Regarding the evaluation of the quality of the technical information from the website, the results obtained from the application of the modification of Health on the Net Code ${ }^{2}$ are presented in Figure 6 . Given that the closer to the maximum score (13 points) improved the technical quality of the website, the Babies Portal was classified as very good. Nevertheless, when analyzing the categories separately, we observed that the criterion Purpose obtained the lowest score, meaning that the objectives of the website were not clear to the user. The categories Author Qualification and Updates were scored higher, suggesting that they could detect this information clearly.

To compare how the users perceive the increase

\begin{tabular}{|l|l|}
\hline Participant & Comments \\
\hline 1 & $\begin{array}{l}\text { "I really enjoyed the Portal, the themes are of great importance and the language is easy to understand, } \\
\text { especially for the lay public. I added the portal as a link in my favorites and I will certainly use it to move } \\
\text { guidance to the parents and I will promote! CONGRATULATIONS !!!!" }\end{array}$ \\
\hline 2 & $\begin{array}{l}\text { "The flap of topics could be a little more organized and divided into the areas of Speech Language Pathology/ } \\
\text { Audiology, and within each area there are the divisions of language topics, for example." }\end{array}$ \\
\hline 3 & $\begin{array}{l}\text { "I wonder if in the example of the hearing health care portal, parents have made content-related questions } \\
\text { in the field of Orofacial Functions" }\end{array}$ \\
\hline 4 & $\begin{array}{l}\text { "On the topic of bottle, pacifier and finger sucking, no tips were present for the withdrawal of harmful } \\
\text { habits, which would make the topic more helpful for mothers. The information is too generic, and a dentist } \\
\text { oxplored. All the other contents were very superficial." }\end{array}$ \\
\hline 5 & $\begin{array}{l}\text { "I found the site to be very well done, with super important information, and easy to understand language } \\
\text { and the videos work were very enriching." }\end{array}$ \\
\hline
\end{tabular}

Figure 5- Speech-language pathologists/audiologists suggestions about the "Orofacial Functions" section of the Babies Portal website

\begin{tabular}{|c|c|c|c|c|c|c|c|c|}
\hline \multicolumn{9}{|c|}{ TECHNICAL QUALITY OF THE WEBSITE } \\
\hline Participant & Ownership & Purpose & Authoring & $\begin{array}{c}\text { Author } \\
\text { qualification }\end{array}$ & Assignment & Interactivity & Updates & $\begin{array}{l}\text { Global } \\
\text { Score }\end{array}$ \\
\hline 1 & 1 & 2 & 2 & 2 & 2 & 2 & 2 & 13 \\
\hline 2 & 1 & 2 & 2 & 2 & 2 & 2 & 2 & 13 \\
\hline 3 & 1 & 2 & 2 & 2 & 1 & 2 & 2 & 12 \\
\hline 4 & 0 & 0 & 2 & 2 & 2 & 2 & 2 & 10 \\
\hline 5 & 1 & 2 & 2 & 2 & 2 & 2 & 2 & 13 \\
\hline 6 & 0 & 0 & 1 & 2 & 0 & 0 & 2 & 5 \\
\hline 7 & 1 & 2 & 2 & 2 & 2 & 2 & 2 & 13 \\
\hline 8 & 1 & 0 & 1 & 2 & 2 & 1 & 2 & 9 \\
\hline 9 & 0 & 2 & 0 & 2 & 0 & 0 & 2 & 6 \\
\hline 10 & 1 & 0 & 0 & 2 & 0 & 2 & 2 & 7 \\
\hline Average & & & & & & & & 10.1 \\
\hline $\begin{array}{l}\text { Standard } \\
\text { Deviation }\end{array}$ & & & & & & & & 3.18 \\
\hline
\end{tabular}

Figure 6- Technical evaluation of the available information in the "Orofacial Functions" section made by the speechlanguage pathologist/audiologists 


\begin{tabular}{|c|c|c|c|c|c|}
\hline & & & & & \\
\hline $\begin{array}{c}\text { Acquisition of } \\
\text { new information }\end{array}$ & $\begin{array}{c}\text { The Oral } \\
\text { Functions }\end{array}$ & Breastfeeding & Food & $\begin{array}{c}\text { Pacifier, Baby } \\
\text { bottle and Finger } \\
\text { sucking }\end{array}$ & Breath \\
\hline No help & - & - & - & - & - \\
\hline Helped a little & 20 & 40 & - & 60 & - \\
\hline Helped & 40 & 20 & 60 & 40 & 60 \\
\hline Helped a lot & 40 & 40 & 40 & 40 \\
\hline
\end{tabular}

Figure 7- Presentation of the percentage of parents as judged by each section of the website, regarding the acquisition of new information about the oral function developments of the baby

of knowledge with the information provided on the website, the participant was asked to carry out an assessment of their general knowledge of the five sections, before the Babies Portal visit. Participants classified a $60 \%$ good level of prior knowledge and $40 \%$ as satisfactory. They said that they had some considerable prior knowledge about what they would have access to on the website.

It might be noted that, in assessing how much the participants learned by addressing each section of the website, most of Group B ( $88 \%$ of the participants on average) reported that the website helped or helped very much in understanding the content covered. The sections "Breath", "Food" and "Pacifier, baby bottle and finger sucking" were the best evaluated, having no instance of the classification "not helped" or "helped little", as shown in Figure 7.

The participants rated the videos in the sections "Breastfeeding" and "Food" as important tools for learning: $60 \%$ of the participants said they helped, and $40 \%$ said they helped very much.

Regarding the website language: it proved to be always adequate to the transmission of content for $20 \%$; for $40 \%$, it sometimes helped; and for $40 \%$, almost. There were no reports that the language "almost never" or "never" helped in understanding the content.

At the moment it was requested that the users rated the Babies Portal quality on the topics "Breastfeeding", "Food", "Pacifier, baby bottle and finger sucking" and "Breath", 40\% indicated that the quality was excellent, another $40 \%$ classified it as good, and $20 \%$ said the quality was regular.

\section{DISCUSSION}

The execution of research in the field of Telehealth in Speech-Language Pathology/Audiology is limited, with the centralization of the work in the Audiology $\operatorname{area}^{25}$. There were not any scientific studies about the development and evaluation of websites in Speech-Language Pathology/Audiology in the
Orofacial Myology area.

Because Orofacial Myology is the area of SpeechLanguage Pathology/Audiology that is closest to Dentistry, we created connections between these areas of knowledge in this website. These connections are considered fundamental, and orofacial alterations treated by a professional dentist often involve risks to the patient's health in what concerns the field of Speech-Language Pathology/ Audiology, and the opposite is also true. Oral breathing is an alteration that exemplifies the joint action of speech-language pathologists/audiologists and dentists, and its consequences include occlusal alterations $^{19}$, low scholastic performances ${ }^{8}$ and alterations in the orofacial functions ${ }^{11}$.

Considering the interdisciplinary character of the Babies Portal website, it is noteworthy to cite the building of the last section, "Remove from the habit of pacifier and finger sucking": the health and human areas performed the work in a collaborative manner, having speech-language pathologists, Dentistry and Psychology professionals gather important contents on the topic in order to compile the material about the removal of the habit with a whole view of the child.

The work of the Ministry of Health on breastfeeding is an important initiative for health promotion, with relevant information for parents and caregivers. Thus, the Babies Portal website provides links to these materials. However, the Oral Functions contents of the Portal address the issue of breastfeeding in a more dynamic way, because it contains illustrations, videos and texts in the form of threads, in addition to covering the contents of food after 6 months of age, harmful oral habits and breath, key aspects for the orofacial development of the baby, which are not available on the Ministry of Health website.

Seeking the scientific support and up-to-date information, the contents displayed on the Babies Portal website were supported in the scientific literature available. However, the language presented in the materials found in the literature 
review was not always accessible to the different target audiences and an adaptation was performed. The available websites researched, although generally seeking to bring their language closer to the users' cultural reality, could not contemplate the contents of the oral functions in a comprehensive way.

The Babies Portal's sections about the Oral Functions obtained an average score of 60.8 points on the Flesch Reading Ease Test, equivalent to a standard level of understanding. In support of this result, the evaluations from the parents and caregivers also judged the sections' language as a helpful contributor to the learning process. The importance of this test is also found in other areas, such as the exact sciences, which use the same to assist in evaluating the reliability of information communicated by texts, regardless of their complexity, with the purpose, in some cases, of distorting the facts to some benefit in some way ${ }^{5}$.

In the result of the modified questionnaire of Health on the Net Code ${ }^{2}$, it was observed that the "Updates" category was one of the best evaluated. This criterion is very important for considering a dynamic method that enables the addressed content updates to convey a more reliable and interesting source of information to the audience ${ }^{24}$. Studies bring the importance of the tool Foundation Health on the Net Code of Conduct to standardize health information websites, allowing for greater benefits to an audience looking for information $n^{7,9}$.

Regarding the website quality, it was similarly noted in the satisfaction level of group $A$ and group $B$, which generally rated the website as excellent and good. This data was probably a result from the work in the collection of up-to-date and reliable information, simplification of language and illustration by means of static and dynamic images.

Concerning the academic formation of the professionals, group $A$ had the most graduates in Speech-Language Pathology/Audiology with a graduation time from 1 to 10 years. It is suggested that future studies include only SpeechLanguage Pathology specialists with a minimum of 5 years of graduation, directing a precision of content evaluation, and have a higher number of participants ${ }^{29}$. It is emphasized that this study conducted a pilot study aimed at improving the instrument.

The results showed that most parents (group B) were assisted in the acquisition of information through access to the related sections of Orofacial Myology. Regarding a website for parents and caregivers about childhood chronic constipation and encopresis, $99 \%$ of the users indicated effectiveness of Information and Communication Technology to assist the audience in the acquisition of new knowledge ${ }^{6}$. Despite the different approaches, the results resemble the findings of this research, expressing to achieve the proposed objectives of distance education.

It is expected that health education, mediated by technology, results in changes in behavior and it is important to supplement it with other primary prevention actions ${ }^{18}$. As an example, the Doctor Youth Project has been promoting actions based directly on interfering positively with the quality of life of students and of the community around ${ }^{23}$.

Thus, the Babies Portal website can be considered an important tool for providing information regarding the proper stimulation of orofacial functions, early diagnosis and prevention of orofacial myofunctional changes during early childhood, which can cause a significant impact on the development of the child.

\section{CONCLUSION}

The sections "The Oral Functions", "Breastfeeding", "Food", "Pacifier, baby bottle and finger sucking" and "Breath" have been prepared and structured, and they are now available at the Babies Portal (http://portaldosbebes.fob.usp.br/portaldosbebes/ Portugues/detSubCategoriaInstitucional. php?codsubcategoria_fono $=73 \&$ codcategoria site $=1$ ) with an adequate level of readability for the target public. The pilot project demonstrated that five sections of the website about the oral functions were of good quality and contributed to the acquisition of new knowledge, in the vision of the parents and professionals.

\section{ACKNOWLEDGMENT}

To the members of Telehealth of the Bauru School of Dentistry, University of São Paulo, the members of the Tutorial Education Program in Speech-Language Pathology/Audiology, the Ministry of Education and Culture, Art Finalist of Bauru School of Dentistry Camila Medina and the IPTV Bauru School of Dentistry, University of São Paulo Experimental team.

\section{REFERENCES}

1- Araújo MF, Del Fiaco A, Pimentel LS, Schmitz BA. Custo e economia da prática do aleitamento materno para a família. Rev Bras Saude Matern Infant. 2004;4(2):135-41.

2- Barbosa AL, Martins EN. Avaliação da informação dos pacientes sobre miopsias e fotopsias através da Internet. Arq Bras Oftalmol. 2007;70(5):839-43.

3- Bernades FF. Respiração bucal: O que os pais sabem a respeito? Rev CEFAC. 1999;1(2):18-25.

4- Bertoldi PM, Felício CM, Matsumoto MA. Efeito da interceptação precoce dos hábitos orais no desenvolvimento da oclusão. PróFono. 2005;17(1):37-44.

5- Biondo-Simões ML, Martynetz J, Ueda FM, Olandoski M. Compreensão do termo de consentimento informado. Rev Col Bras Cir. 2007;34(3):183-8. 
6- Borowitz SM, Ritterband L. Using the Internet to teach parents and children about constipation and encopresis. Med Inform Internet Med. 2001;26(4):283-95.

7- Burneo JG. An evaluation of the quality of epilepsy education on the Canadian World Wide Web. Epilepsy Behav. 2006;8(1):299302.

8- Di Francesco RC, Passerotii G, Paulucci B, Miniti A. Respiração oral na criança: repercussões diferentes de acordo com o diagnóstico. Rev Bras Otorrinolaringol. 2004;70(5):665-70.

9- Golterman L, Banasiak NC. Evaluating web sites: reliable child health resources for parents. Pediatr Nurs. 2011;37(2):81-3.

10- Lamberti LM, Fischer Walker CL, Noiman A, Victora C, Black RE. Breastfeeding and the risk for diarrhea morbidity and mortality. BMC Public Health. 2011;11(Suppl 3):S15.

11- Maciel CT, Leite IC. Aspectos etiológicos da mordida aberta anterior e suas implicações nas funções orofaciais. Pró-Fono. 2005; 17(3):293-302.

12- Maftum MA, Campos JB. Capacitação pedagógica na modalidade de educação a distância: desafio para ativar processos de mudança na formação de profissionais de saúde. Cogitare Enferm. 2008;13(1):132-9.

13- Medeiros APM, Ferreira JTL, Felício CM. Correlação entre métodos de aleitamento, hábitos de sucção e comportamentos orofaciais. Pró-Fono. 2009;21(4):315-9.

14- Ministério da Saúde do Brasil [Internet]. Caderneta do Ministério da Saúde - Vantagens da amamentação. [updated 2007; cited 2012 Apr 02 ]. Avaliable from: http://portal.saude.gov.br/ portal/arquivos/pdf/caderneta_crianca_2007_14.pdf

15- Montaldo L, Montaldo P, Cuccaro P, Caramico N, Minervini G. Effects of feeding on non-nutritive sucking habits and implications on occlusion in mixed dentition. Int J Paediatr Dent. 2011;21:6873.

16- Monte CM, Giugliani ER. Recomendações para alimentação complementar da criança em aleitamento materno. J Pediatr (Rio J). 2004;80(Suppl 5):131-41.

17- Peres KG, Barros AJ, Peres MA, Victora CG. Effects of breastfeeding and sucking habits on malocclusion in a birth cohort study. Rev Saude Publica. 2007;41(3):343-50.

18- Ramalho RA, Saunders C. O papel da educação nutricional no combate às carências nutricionais. Rev Nutr. 2000;13(1):11-6.
19- Retamoso LB, Knop LA, Guariza Filho O, Tanaka OM. Facial and dental alterations according to the breathing pattern. J Appl Oral Sci. 2011;19(2):175-81

20- Santos CS, Lima LS, Javorski M. Fatores que interferem na transição alimentar de crianças entre cinco e oito meses: investigação em Serviço de Puericultura do Recife, Brasil. Rev Bras Saude Matern Infant. 2007;7(4):373-80.

21- Santos MC. Problemas alimentares da infância sem diagnóstico clínico: quando vigiar, quando actuar? Rev Nascer Crescer. 2004;13(4):342-7.

22- Santos VL, Soler ZA, Azoubel R. Alimentação de crianças no primeiro semestre de vida: enfoque no aleitamento materno exclusivo. Rev Bras Saude Matern Infant. 2005;3:283-91.

23- Silva AS, Rizzante FA, Picolini MM, Campos K, Corrêa CC, Franco EC, et al. Bauru School of Dentistry Tele-Health League: an educational strategy research teach and extension among applications in tele-health. J Appl Oral Sci. 2011;19:599-603. 24- Soirefmann M, Boza JC, Comparin C, Cestari TF, Wen CL. Cybertutor: um objeto de ensino na Dermatologia. An Bras Dermatol. 2010;85(3):400-2.

25- Spinardi AC, Blasca WQ, Wen CL, Maximino LP. Telefonoaudiologia: ciência e tecnologia em saúde. Pró-Fono. 2009;21(3):249-54.

26- Suliano AA, Rodrigues MJ, França Caldas A Jr, Fonte PP, PortoCarreiro CF. Prevalência de maloclusão e sua associação com alterações funcionais do sistema estomatognático entre escolares. Cad Saude Publica. 2007;23(8):1913-23.

27- Vieira GO, Silva LR, Vieira TO, Almeida JA, Cabral VA. Hábitos alimentares de crianças menores de 1 ano amamentadas e nãoamamentadas. J Pediatr (Rio J). 2004;80(5):411-6.

28- Zapata M, Bachiega JC, Marangoni AF, Jeremias JE, Ferrari RA, Bussadori SK, et al. Ocorrência de mordida aberta anterior e hábitos bucais deletérios em crianças de 4 a 6 anos. Rev CEFAC. 2010;12(2):267-71.

29- Zem-Mascarenhas SH, Cassiani SH. Desenvolvimento e avaliação de um software educacional para o ensino de enfermagem pediátrica. Rev Latino-Am Enfermagem 2001;9(6):13-8. 